\title{
Hydrographic observations and model results from a PRISMA drift experiment
}

\author{
Peter König ${ }^{1, *}$, Corinna Schrum ${ }^{2}$ \\ 'Bundesamt für Seeschiffahrt und Hydrographie, Bernhard-Nocht-Str. 78, D-20359 Hamburg, Germany \\ ${ }^{2}$ Zentrum für Meeres- und Klimaforschung der Universität Hamburg, Institut für Meereskunde, Troplowitzstr. 7 , \\ D-22529 Hamburg, Germany
}

\begin{abstract}
A drift experiment was conducted from 23 to 29 April 1991 in the central western part of the German Bight as part of the German research program PRISMA. Observed hydrographic time series and results from a numerical model are presented. The discussion focuses on the problem of whether the drift buoy used was suitable for marking a 'selected water body' in order to study specific processes. Based upon the data and the model outcome, the experiment had to be divided into 2 phases. During the first phase the drift buoy was situated in denser water with relatively low concentrations of suspended particulate matter (SPM) and phytoplankton. On 26-27 April, a storm event initiated the second phase. The buoy was then forced to deviate from its expected position into a water mass of a more coastal type characterized by slightly higher temperatures, lower salinity and lower transmission. Concentrations of phytoplankton and SPM increased. The passage of a weak salinity front between 2 stations on 29 April was identified in the data as well as in the simulated salinity distribution.
\end{abstract}

KEY WORDS: German Bight - Drift experiment - Drogue $\cdot$ Numerical model $\cdot$ Hydrography

\section{INTRODUCTION}

Between 23 and 29 April 1991, a drift experiment was conducted in the central western part of the German Bight as part of the German research project PRISMA. To identify processes in the ecosystem, several parameters were measured in the water and in the atmosphere near a drifting buoy and its immediate vicinity by RV 'Valdivia', which followed the buoy during the entire drift time. Besides field measurements, numerical models were developed to simulate the dispersion of dissolved and particulate contaminants in the water and atmosphere as well as the transfer of contaminants within the ecosystem by plankton.

This paper presents time series of oceanographic observations from the drift experiment and discusses why the drift buoy failed to mark the selected water body. Results from a numerical model, which proved to be a basic requirement for the interpretation of the observed data, are taken into account.

-E-mail: peter.koenig@bsh.d400.de

\section{DESIGN OF THE EXPERIMENT}

The standard approach for performing investigations in the open sea is the Eulerian one, i.e. investigations are based on measurements repeated at geographically fixed stations. In the German Bight, where nearly all parameters show strong gradients towards the coast, data sets usually display a strong tidal signal. The advection of water masses of different origin to the fixed position of a station complicates the study of biological and chemical processes that dominate the phase distribution (dissolved/particulate) of organic contaminants and heavy metal. For that reason the PRISMA project groups conducted a Lagrangian flow experiment (drift experiment), in which a research vessel followed a 'defined water mass'. To achieve this goal several approaches were considered, but all of them have disadvantages. A usual technique is to release an artificial tracer like the non-toxic red dye rhodamine- $\mathrm{B}$, which can easily be detected by its fluorescence (Kullenberg 1974, Talbot \& Talbot 1974). This method requires a lot of ship time to map the location 


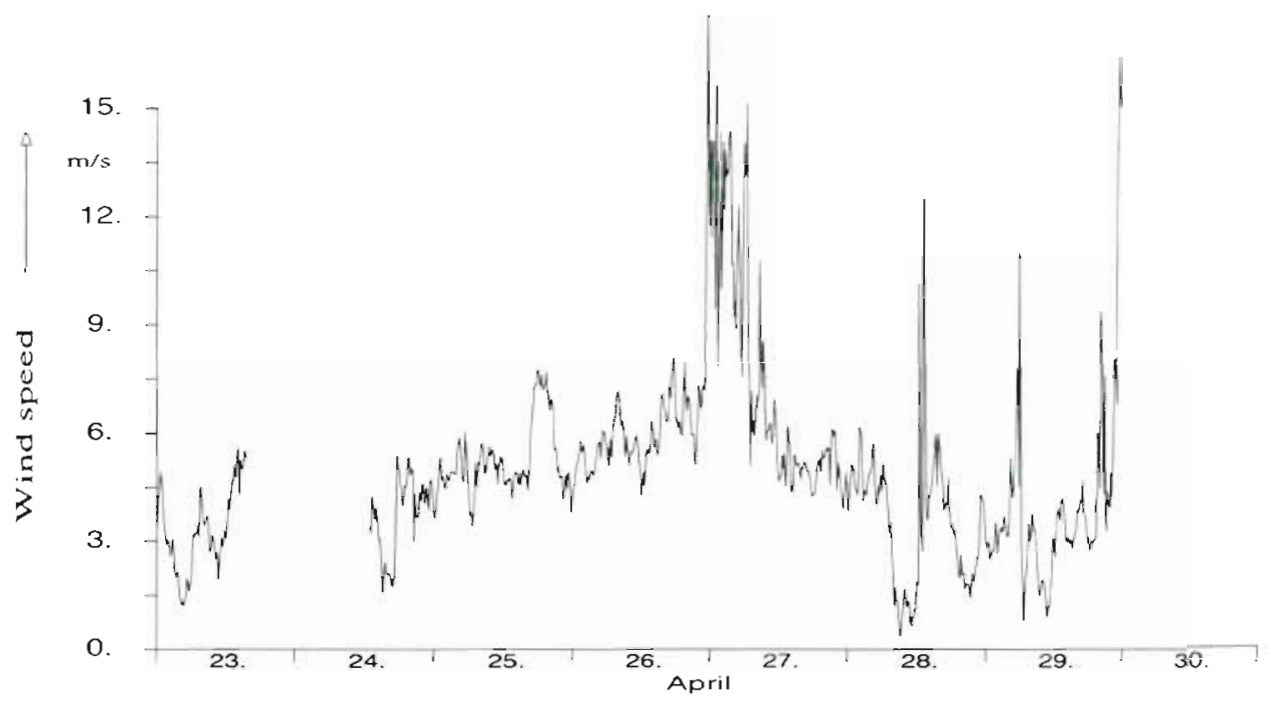

Fig. 1. Time series of wind speed aboard RV 'Valdivia' during the drift experiment

and the center of the dye patch. Moreover, there is a risk that the dye may affect the biological processes in the water body to be examined. Another method of marking a water mass is to use a drogue fitted to a position buoy. A drogue, however, does not exactly follow the same route as the surrounding water mass (Booth 1981). Wind drag and subsurface drag (caused by surface currents and waves) act on the surface buoy and may support its movement in a direction different from that of the drogue. A vertical gradient in the current velocity, moreover, means that the movement of a drogue is representative only of water at the drogue's depth and not, as intended, of the larger water mass above and below.

For the PRISMA process studies a cruciform drogue $3 \mathrm{~m}$ below the surface was fitted to a surface buoy. The drag element consisted of crossed sails with a total area of about $12 \mathrm{~m}^{2}$. This type of buoy has been used by the Bundesamt für Seeschiffahrt und Hydrographie (BSH) for about 20 yr. Measurements with these buoys have shown that they may drift away from the originally marked water mass at 0.5 to $0.6 \%$ of the wind speed (Weidemann 1984). For our experiment, with low to moderate winds (Fig. 1), this corresponds to a distance between 1 and $9 \mathrm{~km} \mathrm{~d}^{-1}$. In addition to the usual design, a $20 \mathrm{~m}$ chain with 3 small sediment traps and a weight was attached below the drogue. This vertical extension of the drogue to a deeper level implies the possibility that a change of water speed and/or direction in that layer could have influenced the movement of the whole system including the surface buoy. The drifter system was released and tracked by RV 'Valdivia' over the entire period. For easier detection. the buoy was equipped with a radar reflector.

The drift experiment began at 18:00 h UTC on 23 April and ended at 18:00 h UTC on 29 April 1991. The release point for the buoy was chosen based on information provided by RV 'Gauss', which investigated various ecosystem parameters along an equally spaced rectangular station grid covering almost all of the German Bight (Schrum et al. 1997 in this volume). The experimental site was approximately $74 \mathrm{~km}$ northwest of the island of Helgoland in $35 \mathrm{~m}$ of water. Within $6 \mathrm{~d}$, the buoy had drifted along a 'zigzag' course about $24 \mathrm{~km}$ to the south (Fig, 2).

RV 'Valdivia' conducted all measurements in the drift area. A Neil Brown Instruments Mark III CTD and a $10 \mathrm{~cm}$ path-length, $660 \mathrm{~nm}$ light transmissometer (Sea Tech, Corvallis, OR) measured profiles of temperature, conductivity and total transmission. In combination with the CTD, a rosette system with twelve $10 \mathrm{l}$ bottles was used for water sampling. Every 6 h CTD profiles and water samples (e.g. nutrients, phytoplankton, zooplankton, cadmium, lead, $\alpha-\mathrm{HCH}, \gamma-\mathrm{HCH})$ were taken near the buoy (Stn Z) and at 3 stations $5.6 \mathrm{~km}$ ( 3 nautical miles) away in southerly, northwesterly and northeasterly directions (Stns S, NW and NE).

Because suspended particulate matter (SPM) is an important carrier of contaminants such as heavy metals, water samples were taken and their SPM and heavy metal contents were measured. SPM was concentrated on a pre-weighed $47 \mathrm{~mm}$ diameter $0.45 \mu \mathrm{m}$ pore size polycarbonate membrane (Nuclepore). The SPM dry weight was measured in the laboratory at a later date.

Weather conditions were normal for April and corresponded well to the mean monthly values of the last 4 yr. About 1 wk before the drift experiment, a storm low moved from the northern North Atlantic to Scandinavia and caused stormy weather with winds from the NNW. These winds caused waves with significant wave heights up to $4.5 \mathrm{~m}$ (Bundesamt für Seeschiffahrt und Hydrographie 1992) and strong vertical mixing of the water masses in the German Bight. The sea remained predominantly calm until the end of the experimental period. For most of the time during the drift ex- 


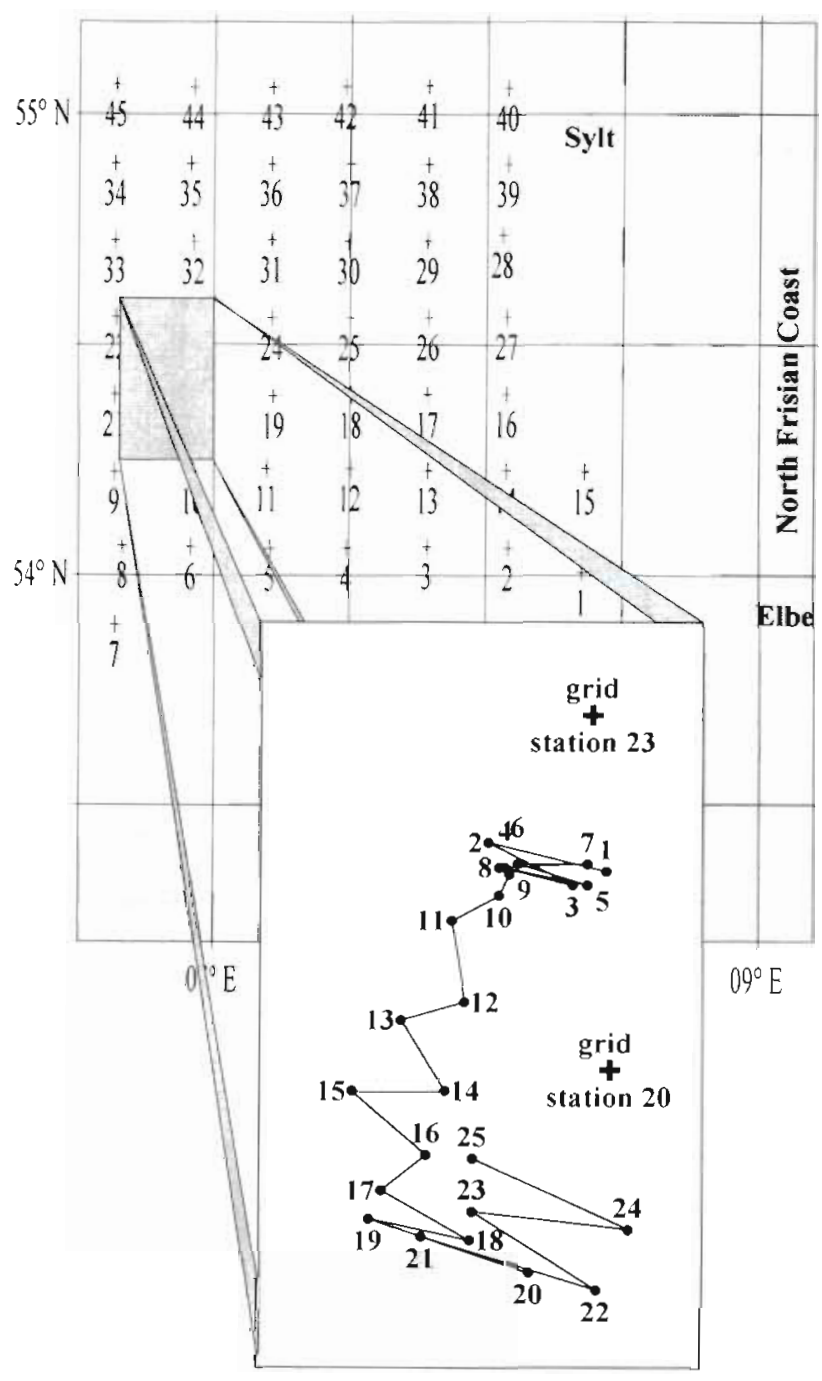

Fig. 2. Movement of the drift buoy in the German Bight (numbered dots indicate positions every 6 h) and area of measurements (with station numbers). (Courtesy of $T$ Raabe) periment, a high-pressure area over Scandinavia determined the weather conditions (Deutscher Wetterdienst 1991, Schrum et al. 1997). Winds predominated from easterly directions with speeds mainly below $6 \mathrm{~m} \mathrm{~s}^{-1}$ (Fig. 1). An increase in wind speed to $>12 \mathrm{~m} \mathrm{~s}^{-1}$ was observed only from 26 to 27 April, when a low at upper air levels moved from the Baltic Sea into the German Bight.

\section{RESULTS FROM HYDROGRAPHIC OBSERVATIONS}

The RV 'Gauss' hydrographic data set shows normal seasonal warming of the water temperatures in the German Bight for the period of the cruise. The temperatures corresponded well to the long-term mean (1902 to 1954). The 34 psu isohaline had advanced southwards far into the German Bight before the drift experiment began. Due to the prevailing easterly winds, upwelling of colder water was observed northwest to west of Helgoland in the post-glacial Elbe River valley (Schrum et al. 1997). This upwelling compensated for the offshore Ekman transport (Becker et al. 1992). The region of the PRISMA drift experiment was located west of this upwelling region, but was still in an area where meanders and upwelling fronts may occur.

All data described in the following were obtained along the path of and near the drift buoy. During the whole experiment, all water parameters established significant horizontal gradients between all 4 stations. Compared to the drifter's position (Stn Z) temperatures were mainly higher at Stn NW and lower at Stn NE (each by about $0.2^{\circ} \mathrm{C}$ ). The lower temperatures at Stn NE reflect its proximity to the upwelling region west of Helgoland. Temperatures at Stns S and Z were similar, except on 25 and 26 April, when Stn S showed values about $0.15^{\circ} \mathrm{C}$ higher. Stn $\mathrm{S}$ always had lower salinity than Stn Z (up to 0.09 psu), while at the northern stations (NE, NW) higher values predominated (Fig. 3).
Fig. 3. Time series of salinity (psu) at $10 \mathrm{~m}$ depth at $\operatorname{Stn} \mathrm{Z}(\mathrm{Z})$, Stn NE $(X)$ and $\operatorname{Stn} S(O)$

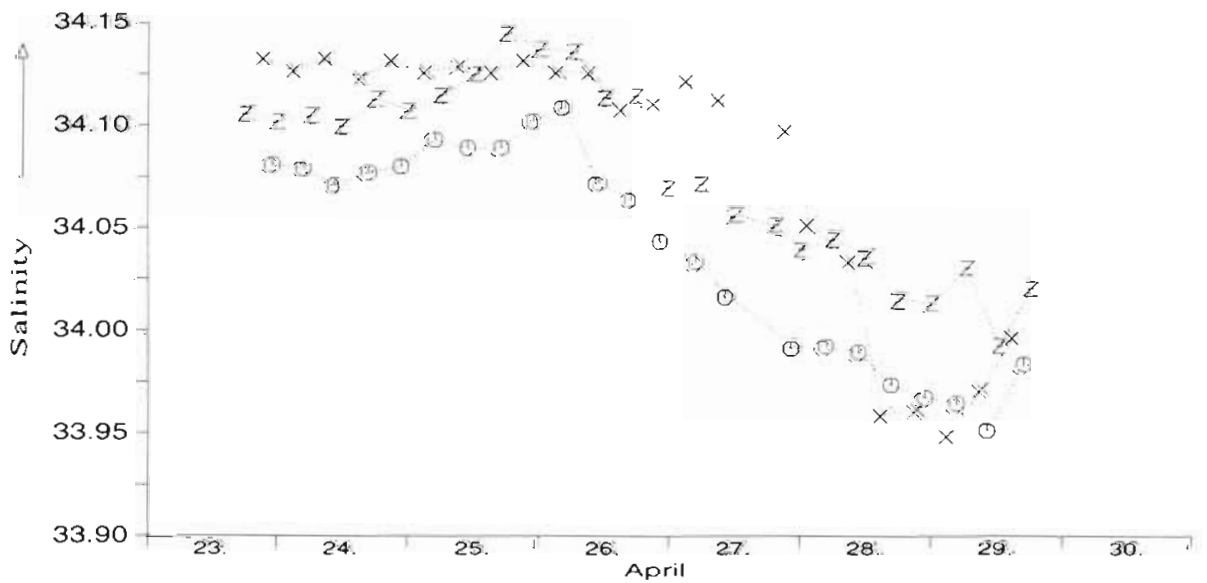




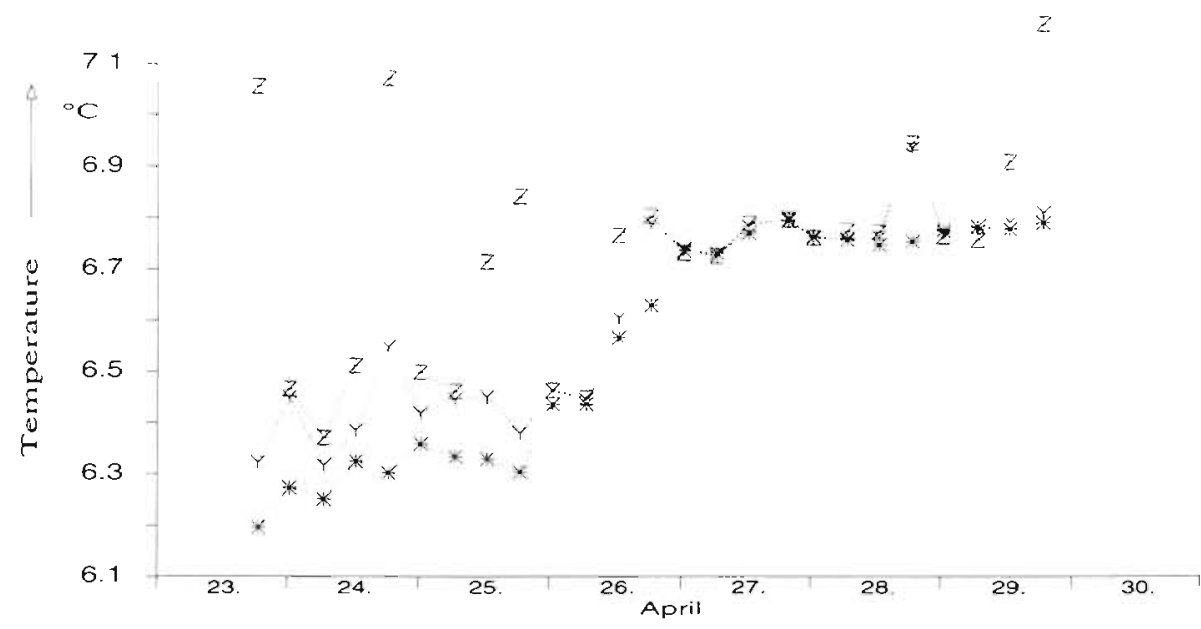

Fig. 4. Time series of temperature $\left({ }^{\circ} \mathrm{C}\right)$ at $5 \mathrm{~m}(\mathrm{Z}), 10 \mathrm{~m}(\mathrm{Y})$ and $30 \mathrm{~m}$ depth (*) near the drifter (Stn Z)

During the first days of the drift experiment, strong daily variations of up to $0.7^{\circ} \mathrm{C}$ were measured in the temperature near the surface (Fig. 4). This daily signal was not observed at or below the $20 \mathrm{~m}$ sampling depth. During 25-26 April, the temperature of the whole water column increased by about $0.4^{\circ} \mathrm{C}$; afterwards it remained stable around $6.8^{\circ} \mathrm{C}$ aside from the daily warming cycle. The increase in temperature was followed by a decline in salinity and density after 25 April. Variations in salinity with depth were only about 0.02 psu. At $30 \mathrm{~m}$ depth ( $\operatorname{Stn} \mathrm{Z}$ ), water density decreased from $26.84 \mathrm{~kg} \mathrm{~m}^{-3}$ (25 April) to $26.71 \mathrm{~kg} \mathrm{~m}^{-3}$ (29 April). This trend was observed at all depths and stations.

Between 23 and 25 April transmission at Stn Z was about $88 \%$ at $5 \mathrm{~m}$ depth, with lower values towards the bottom (up to $-6 \%$ at $30 \mathrm{~m}$ depth). On the last $2 \mathrm{~d}$ of the experiment the transmission was reduced by $7 \%$. The geographic distribution shows lower transmission (corresponding to higher turbidity) at Stn $\mathrm{S}$ and higher values at Stns NE and NW compared to the drifter Stn Z.

All these observations suggest that the drifter moved into another water mass comprising a more coastal type of water characterized by slightly higher temper- atures, lower salinity and lower transmission. The observed increase of wind speed to more than $12 \mathrm{~m} \mathrm{~s}^{-1}$ and a change in wind direction during the night of 26 to 27 April were the reasons.

The SPM time series at $10 \mathrm{~m}$ depth (M. Haarich pers. comm.) is shown in Fig. 5. In the first phase of the drift experiment, SPM content at $10 \mathrm{~m}$ depth was low: $1.0 \pm 0.2 \mathrm{mg} \mathrm{l}^{-1}$. On 27 April, a sudden increase to $7.0 \mathrm{mg} \mathrm{l}^{-1}$ followed by a slow decrease was observed. No interpretation for the maximum value can be given now. An error in measurement is unlikely. The time series of SPM supports the thesis that the drifter moved through 2 different water masses.

The same is true for the nutrient and the phytoplankton data at Stn Z (Raabe et al. 1997 in this volume). During the first $3 \mathrm{~d}$ of the drift trial, concentrations of nitrate and nitrite at $10 \mathrm{~m}$ depth remained quite stable. Time series for phytoplankton concentrations at the same depth show low median values of about $1.8 \mathrm{mg}$ $\mathrm{C} \mathrm{m}^{-3}$. On 26 April, all nutrients and the biomass showed sudden changes in concentrations, accompanied by a shift in temperature and salinity. Phytoplankton biomass, which was mainly composed of Phaeocystis globosa (95\%), increased to $285 \mathrm{mg} \mathrm{C} \mathrm{m}^{-3}$.

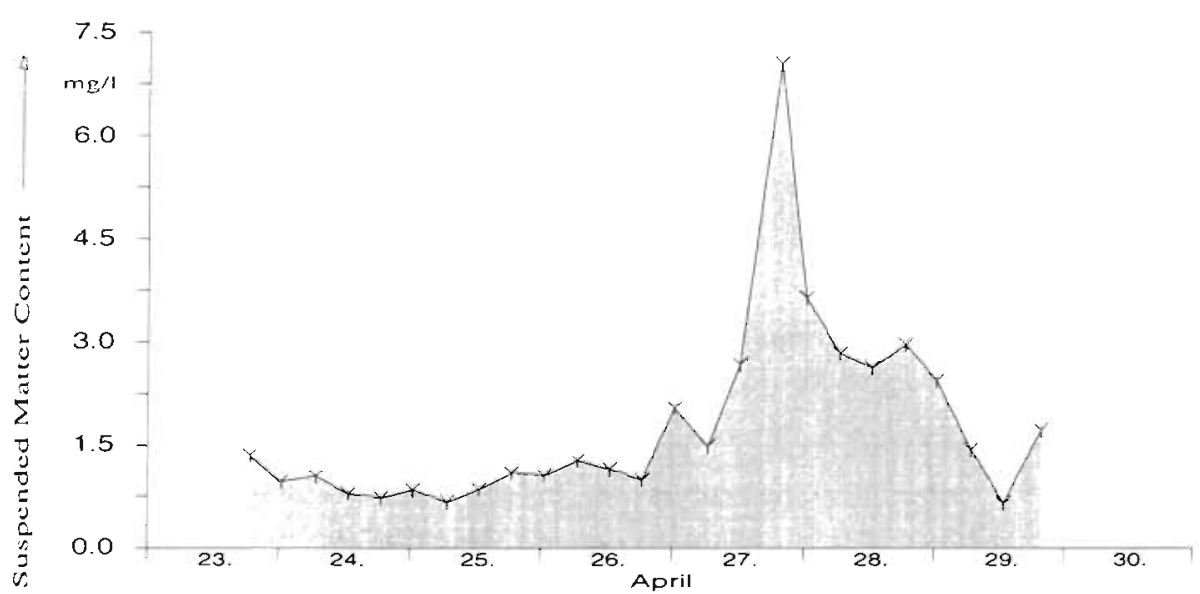

Fig. 5. Time series of suspended particulate matter (mg $\left.\mathrm{i}^{-1}\right)$ at $10 \mathrm{~m}$ depth near the drifter (Stn Z) 
Table 1 Relative values of various physical variables at $\operatorname{Stn} \mathrm{Z}$ at different times during the drift experiment. L: lower values; $T$ : transition; $\mathrm{H}$ : higher values

\begin{tabular}{|c|c|c|c|c|c|c|c|}
\hline & Temperature & Salinity & Density & Transmission & SPM & $\begin{array}{l}\text { Phosphate, } \\
\text { nitrate/nitrite }\end{array}$ & $\begin{array}{l}\text { Phyto- } \\
\text { plankton }\end{array}$ \\
\hline 23-25 April & $\mathrm{L}$ & $\mathrm{H}$ & $\mathrm{H}$ & $\mathrm{H}$ & L & $\mathrm{H}$ & $\mathrm{L}$ \\
\hline 26-27 April & $\mathrm{T}$ & $T$ & $\mathrm{~T}$ & $\mathrm{~T}$ & $\mathrm{~T}$ & $\mathrm{~T}$ & $\mathrm{~T}$ \\
\hline 28-30 April & $\mathrm{H}$ & $\mathrm{L}$ & $\mathrm{L}$ & L & $\mathrm{H}$ & $\mathrm{L}$ & $\mathrm{H}$ \\
\hline
\end{tabular}

Looking at the time series of several physical variables (Table 1), we can clearly distinguish between 3 periods with different hydrographic characteristics:

At $\operatorname{Stn}$ NE the time series of salinity reveals another event worth mentioning. On 28 April, a distinct decrease in salinity (about 0.08 psu) was observed, with lowest values compared to the other 3 stations (NW, S, Z). On 29 April, salinity returned to normal, i.e. to values closer to those observed at Stn $Z$. This indicates a meandering of a weak salinity front between the drift buoy and Stn NE. Model results support this hypothesis

\section{MODEL RESULTS: TRAJECTORIES OF THE WATER BODY AND THE DRIFT BUOY}

A numerical model was used to simulate the baroclinic currents in the German Bight and the trajectories of water particles in the drift area. The model is an application of the Hamburg Shelf Ocean Model (HAMSOM). With a resolution of about $2800 \mathrm{~m}$ in the horizontal, $5 \mathrm{~m}$ in the vertical and a time step of $5 \mathrm{~min}$, the model design is an appropriate and essential tool for the interpretation of the data set from the drift experiment. A description of the model and its results for the first PRISMA cruise is given by Schrum $(1994,1997)$ and Schrum et al. (1997).

The model was used in particular to simulate the trajectory of the drift buoy. Model currents from different depths and different wind-drag-dependent factors were considered in order to find the best fit between the model simulations and the observed track of the drifter. The best agreement was found by taking the simulated current from the $6.5 \mathrm{~m}$ depth level and adding a drift velocity of $1.2 \%$ of the wind speed. The factor $1.2 \%$ is higher than the one already cited (Weidemann 1984) because the numerical model uses wind speed data from an analysis (Luthardt 1987) of 3hourly meteorological observations, which were prepared from the 'Deutscher Wetterdienst Seewetteramt Hamburg'. These wind speed data are sometimes underestimated compared to the actual data measured aboard RV 'Valdivia'.

First, calculations were carried out disregarding any wind influence on the movement of the drift buoy. Estimates for the 4, 6.5, 10 and $22 \mathrm{~m}$ depths yielded displacements (i.e. discrepancies) of up to $8 \mathrm{~km}$ over $24 \mathrm{~h}$ between the simulated positions of the water particles and the observed positions (Fig. 6). A comparison with observed wind speed (Fig. 2) shows good agreement between wind speed and displacement; periods with stronger winds resulted in greater displacements. Fig. 6 also presents the result of calculations where a drift velocity of $1.2 \%$ of the wind speed was added to the simulated water particle movement at $6.5 \mathrm{~m}$ depth.

Trajectories of water particles were also computed (Fig. 7). The starting point was the actual position of the drifter at the beginning of the experiment. These
Fig. 6. Displacement for $24 \mathrm{~h}$ periods between the water particles at selected depth levels (modelled) and the drift buoy (observed). Selected depth levels: (+) $4 \mathrm{~m},(x) 6.5 \mathrm{~m},(*) 10 \mathrm{~m}$, (Z) $22 \mathrm{~m}$. (O) Result of calculations where a drift velocity of $1.2 \%$ of the wind speed was added to the water particle movement at $6.5 \mathrm{~m}$ depth

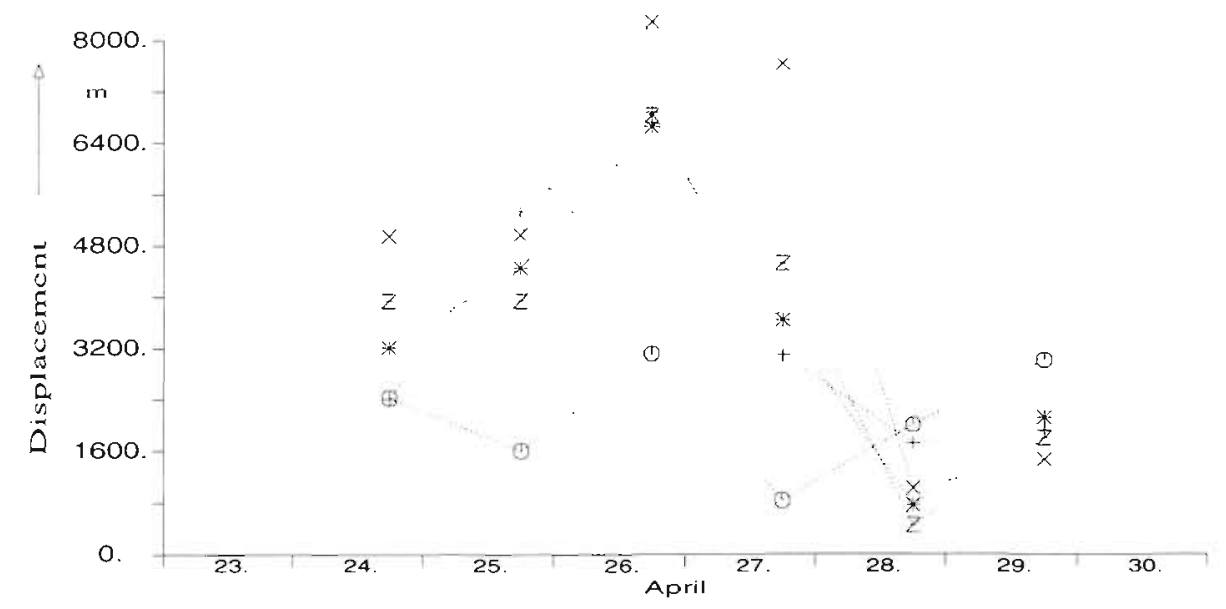




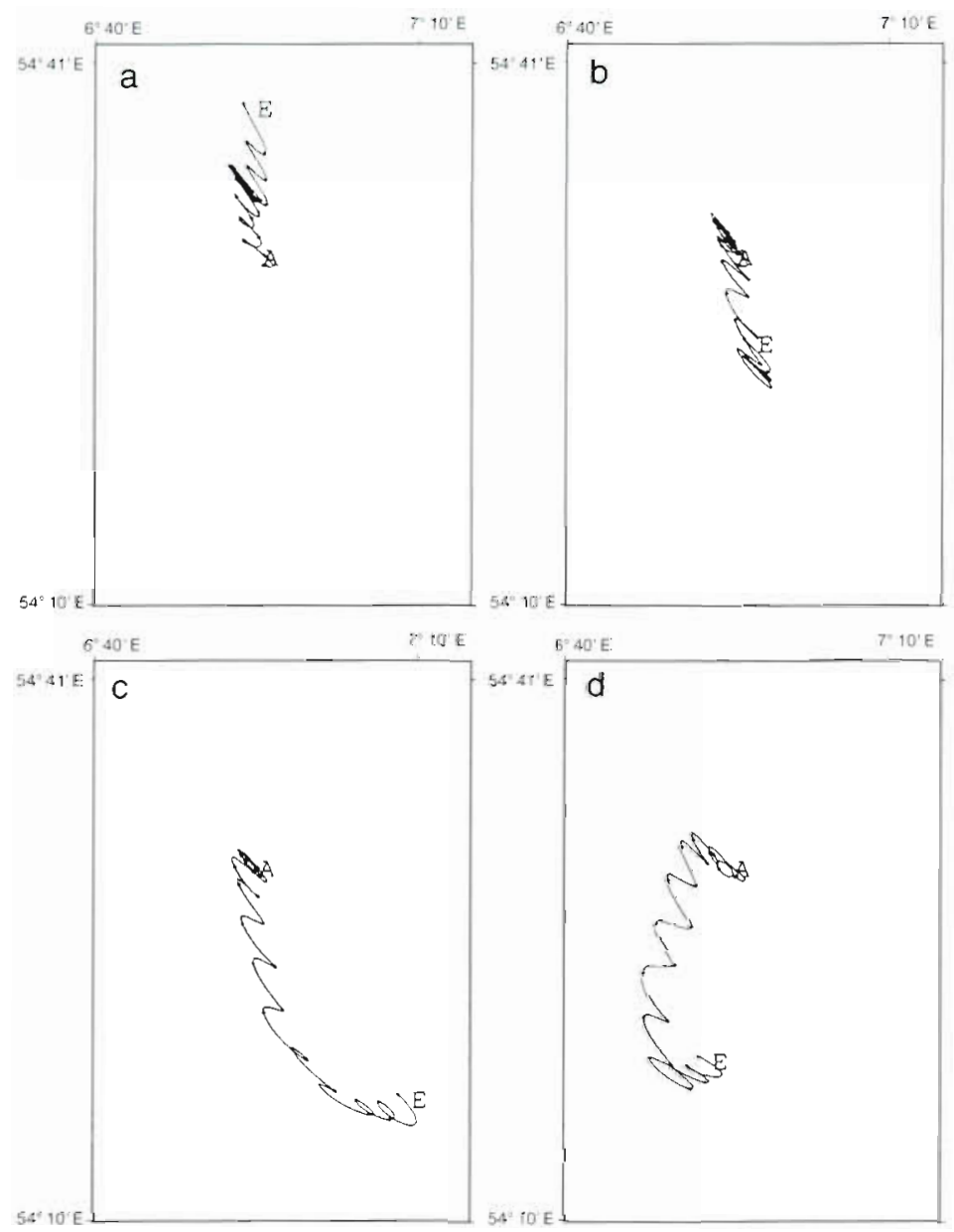

Fig. 7 Model results: trajectories of water particles at (a) $4 \mathrm{~m}$, (b) $6.5 \mathrm{~m}$. (c) $22 \mathrm{~m}$ and (d) $6.5 \mathrm{~m}$ with $1.2 \%$ wind speed added. (' $\mathrm{A}$ ' = start, 'E' = end)

simulations show great differences between trajectories for different depth levels. During the $5 \mathrm{~d}$ of the experiment, the surface and bottom water moved about $30 \mathrm{~km}$ apart, while the water body in the 5 to $10 \mathrm{~m}$ depth range reached a distance of $12 \mathrm{~km}$ from the drift buoy. Simulations over $5 \mathrm{~d}$ for the depth level of $6.5 \mathrm{~m}$ with an added velocity of $1.2 \%$ of the wind speed resulted in a displacement between modelled and observed position of the drift buoy of about $2.5 \mathrm{~km}$; this is an acceptable result.

To sum up, the model simulations clearly indicate that the wind forced the drift buoy to leave the original water mass and that a strong vertical current shear controlled the distortion of the water column at the drifter's position.

The various directions of the simulated water flow at different depth levels are due to the prevailing easterly winds. In the German Bight, this wind usually establishes a strong vertical shear between the simulated horizontal currents in the first $10 \mathrm{~m}$ of the water column (Backhaus 1980, Schrum 1994, 1997). At the end of
April 27, the wind changed direction, becoming northwesterly, and the vertical shear vanished.

Additionally, the numerical model simulates the distribution of temperature and salinity in the German Bight for every time step. Fig 8 shows the calculated distribution of salinity for 21:00 h UTC on 28 April 1991. To obtain this result, the model was initialized by a climatological mean distribution which did not reflect the high positive salinity anomaly in 1990 and 1991. The model therefore shows lower salinities than those observed. Nevertheless, structures and tendencies of the salinity distribution were reproduced quite well (Schrum et al. 1997). Fig. 8 shows that a wedge of highly saline water reaches far into the German Bight along the 54th parallel. The actual positions of the drifter (Stn Z) and of Stn NE are marked on the figure. The strongest gradient in salinity near $\operatorname{Stn} Z$ points northeastwards and explains the observed abrupt change in salinity (0.08 psu) at Stn NE (Fig. 4). The model suggests that the station may have crossed a weak meandering salinity front into an area of lower salinity.

\section{CONCLUSIONS}

The data measured at Stn $Z$ were placed in the context of the observed data from the drift area and the mesoscale field. The evaluation shows that the experiment was adequate for a reliable interpretation of the ecosystem parameters. The coupling of field work and model calculations was an important and necessary feature for a better understanding of the complex processes in the sea. No current-meter data were available for the region of interest, but trajectories of water particles at different depth levels were successfully simulated by means of a numerical model.

The drift experiment had to be divided post hoc into 2 phases. During the first phase (23 to 26 April) denser water with relatively low concentrations of suspended matter and phytoplankton was found. While the surface water moved northwards, the water surrounding the drogue ( 3 to $10 \mathrm{~m}$ depth) moved southwards. A strong vertical current shear controlled the distortion of the water column at the drifter's position. The displacement between the observed position of the drift buoy and the water particles at different depths, as calculated by the model, reached distances of up to $21 \mathrm{~km}$. On 26-27 April, wind speed increased to more than $12 \mathrm{~m} \mathrm{~s}^{-1}$ for a short period. This storm event marked the start of the second phase. The drift buoy deviated from its expected position and then entered a 
Fig. 8. Model results for distribution of salinity (psu) at $10 \mathrm{~m}$ depth at 21:00 h UTC on 28 April 1991. Stns Z $(+)$ and NE (O) are shown

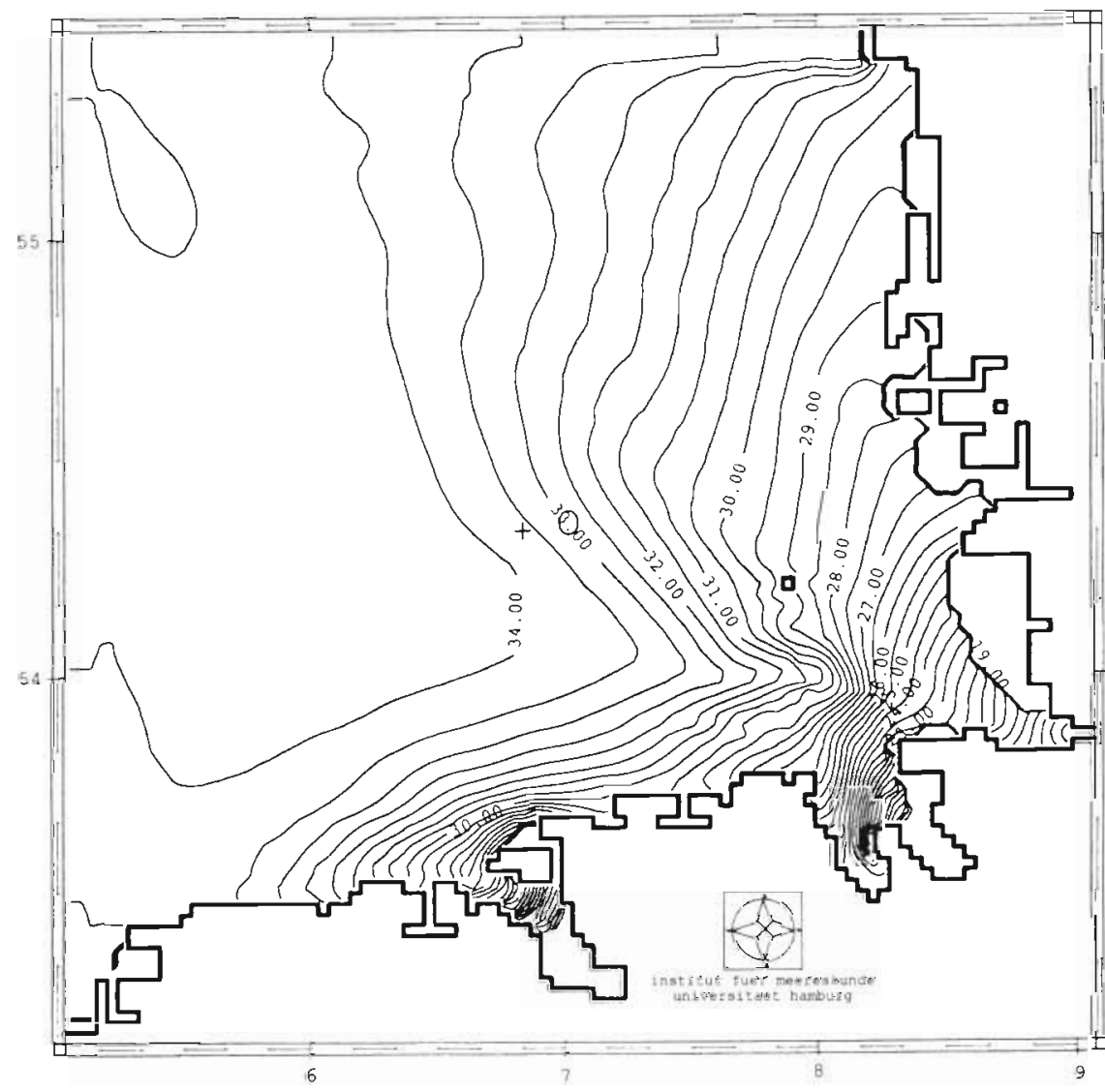

water body with a different parameter constellation. At the buoy's new position, all data showed a water mass of a more coastal type characterized by slightly higher temperatures, lower salinity and lower transmission. Concentrations of phytoplankton and SPM increased. The passage of a weak salinity front between Stns Z and NE on 29 April was identified in the data as well as in the salinity distribution from the model.

Acknowledgements. We are grateful to the officers and crew of RV 'Valdivia' for their help and teamwork during the cruise. Thanks to F. Dobberphul, H.-J. Hobus and K. Schulze for doing the CTD work at sea and P. Wöckel for maintaining the CTD system. Processing of the CTD data was done with the help of $\mathrm{H}$. Bartmuß, M. Kasianowski, F. Kozerski, S. Palkowski, C. Senet and G. Stelter This project was financed in part by the Bundesministerium für Forschung und Technologie (MFU0614, 03F0558A1).

\section{LITERATURE CITED}

Backhaus JO (1980) Simulation von Bewegungsvorgängen in der Deutschen Bucht. Dtsch Hydrogr Z, Erg-H Reihe B, 15

Becker GA, Dick S, Dippner JW (1992) Hydrography of the German Bight. Mar Ecol Prog Ser 91:9-18

Booth DA (1981) On the use of drogues for measuring subsurface ocean currents. Dtsch Hydrogr Z 34:284-294
Bundesamt für Seeschiffahrt und Hydrographie (1992) Seegangsmessungen in der Deutschen Bucht im Jahre 1991 Meereskundl Beob Erg 74

Deutscher Wetterdienst (1991) Europäischer Wetterbericht (European Meteorological Bulletin), Vol 16, Nos. 107 to 119. Deutscher Wetterdienst, Offenbach

Kullenberg G (1974) Investigations on dispersion in stratified vertical shear flow. Rapp P-V Réun Cons Int Explor Mer 167:86-92

Luthardt $\mathrm{H}$ (1987) Analyse der wassernahen Druck- und Windfelder über der Nordsee aus Routinebeobachtungen. Hamb Geophys Einzelschr 83

Raabe TU, Brockmann UH, Dürselen CD, Krause M, Rick HJ (1997) Nutrient and plankton dynamics during a spring drift experiment in the German Bight. Mar Ecol Prog Ser 156:275-288

Schrum C (1994) Numerische Simulation thermodynamischer Prozesse in der Deutschen Bucht. Ber Zentr Meeres- Klimaforsch, Reihe B: Ozeanogr 15

Schrum C (1997) Thermohaline stratification and instability at tidal mixing fronts: results of an eddy resolving model for the German Bight. Cont Shelf Res 17 (6):689-716

Schrum C, König P, Michaelsen K, Niemeier U, Pohlmann T (1997) The meteorological and oceanographic situation in the German Bight from 23 to 29 April 1991. Mar Ecol Prog Ser 156:263-273

Talbot JW, Talbot GA (1974) Diffusion in shallow seas and in English coastal and estuarine waters. Rapp P-V Réun Cons Int Explor Mer 167:93-110

Weidemann $H$ (1984) Tracer diffusion experiments during FLEX 76. Rapp P-V Réun Cons Int Explor Mer 185:39-66 